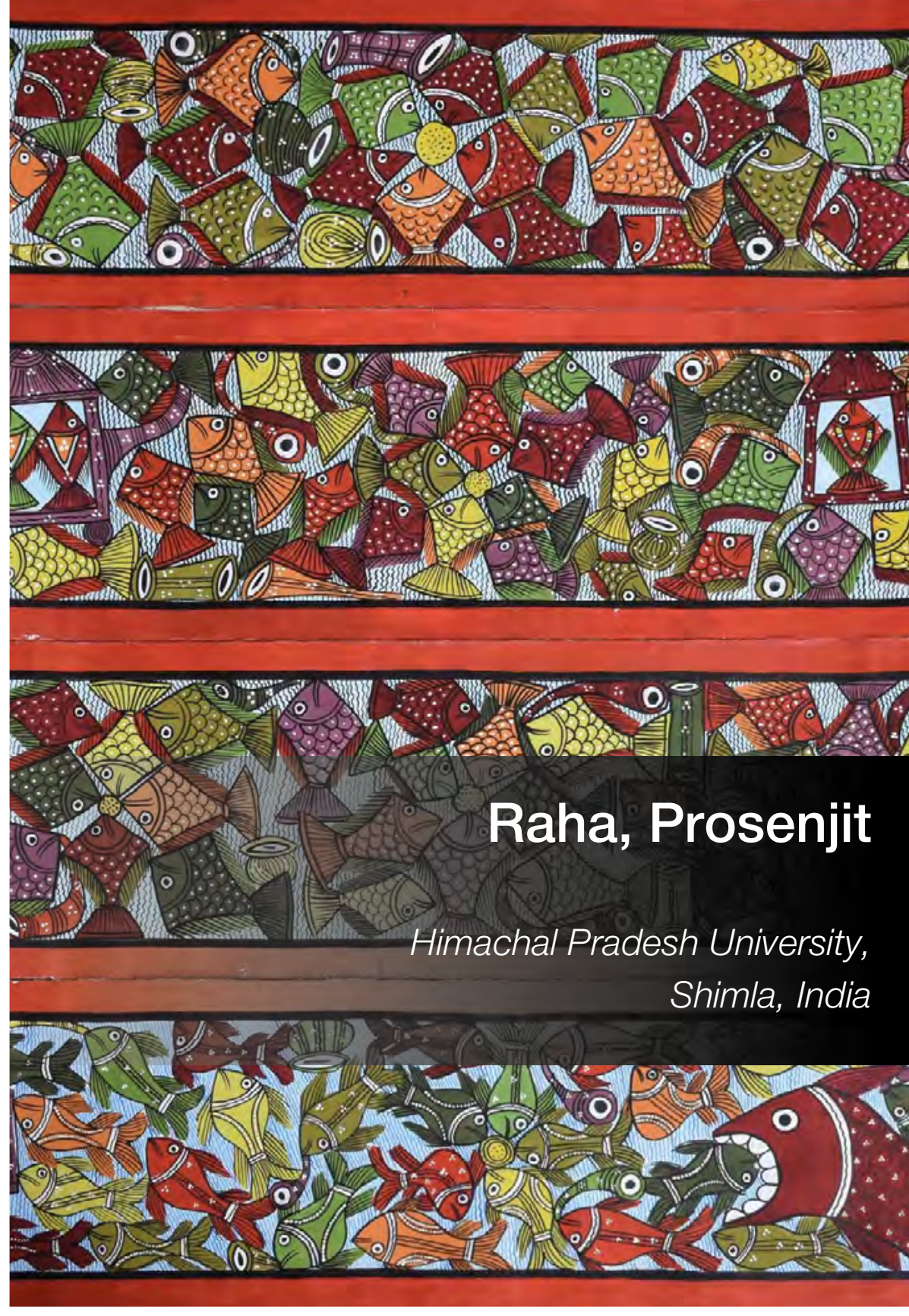

\title{
Раха Просенджит
}

Университет штата Химачал-Прадеш, г. Шимла, Индия

\section{THE PATUAS OF NAYAGRAM:} A JOURNEY AND ITS UPS AND DOWNS

ПАТУА ИЗ НАЯГРАМА:

ПУТЬ, ВЗЛЕТЫ И ПАДЕНИЯ 
Эта исследовательская работа была бы невозможна без поддержки профессора Хим Чаттерджи (выдающегося художника и профессора изобразительного искусства Университета Химачал-Прадеша (HPU)). Автор также благодарит профессора Панкаджа Гупту (HPU), который очень поощряет проведение подобных исследований. Кроме того, плодотворным оказалось сотрудничество с художественной галереей в Шимле.

\section{ACKNOWLEDGMENTS:}

This research paper could not be possible without the inspiration of Prof. Him Chatterjee (Eminent artist and Professor of Visual Art, Himachal Pradesh University (HPU)). The author would also like to mention here Prof. Pankaj Gupta (HPU) who encourages a lot to do good research. Author also got cooperation in this research from the Sanath Art Foundation — the art gallery, Shimla.

\section{АННОТАЦИЯ}

Статья посвящена патачитре - виду народной живописи, популярной, в оснОВном, в индийских штатах Западная Бенгалия и Одиша. Она выполняется на ткани с помощью натуральных пигментов и самодельных клеев. Патачитра считается одной из важнейших этнических традиций Индии. Простота, тонкая стилизация, сочетание смелых линий и ярких цветов патачитры, а также ее повествовательность привлекают многих художников и исследователей искусства. Патачитра считалась умирающей традицией, но в последние годы при поддержке ряда государственных и общественных организаций это искусство возродилось, а новое поколение художников-патуа получило признание своих традиционных ремесел и новые рынки для продажи своих работ. В данной работе делается попытка определить пути развития этого вида этнического искусства на примере деревни Наяграм в Западной Бенгалии, жителями которой являются патуа. Статья основана на полевых исследованиях и экспертных интервью с жителями деревни. Обсуждаются инициативы по выявлению имеющихся проблем и предлагаются возможные решения для развития других исчезающих этнических традиций в мире.

\section{КЛЮЧЕВЫЕ СЛОВА:}

Патачитра; патер ган; народное искусство; этнические традиции; Наяграм-Пингла; искусство Западной Бенгалии; индийское народное искусство.

\section{ABSTRACT}

Patachitra is a form of folk painting, popular mainly in the Indian states of West Bengal and Odisha. It is done on cloth by the natural pigments and homemade adhesives. Patachitra is considered as one of the most important ethnic traditions of India. The simplicity and the highly stylized coordination of bold lines and bright colours of Patachitra and its narrative approach of storytelling may attract any of the artists and art researchers. It was considered as a dying tradition. In the recent years, by the support of several government and social organizations, the art has revived. Through their effective initiatives the new generation of the Patuas (Who creates Patachitras) are getting new platform to be recognized for their hereditary skill and new marketplace to sell their work. Nayagram is a village of the Indian state of West Bengal. All the residents of Nayagram are Patuas. This place is getting popularity for the artistic talent of its people, by the support of the government and social organizations. This research paper is trying to identify the means of development for this kind of ethnic art and artists by studding Nayagram as a model. It is mainly a field work based study to know the on ground reality. Shyamsudar Chitrakar, a veteran Patua of Nayagram was interviewed to learn the real history of Nayagram. On the other hand the young talented woman Patua, Sonia Chitrakar was interviewed to know how she is approaching towards the future betterment of this traditional art form and the and her struggle as a woman belonging from such a marginal community. After compiling their inputs with the other information about the village from both the primary and literary sources the research finds the first four families of Patuas of Nayagram who were given land to live by Gunadhar Bishal, a wealthy farmer who was a lover of art as well. Gradually their relatives (Patuas) also started to come to live at Nayagram. Thus the place was identified by the government and social workers as the place of Patuas and the art of Patachitra. This Paper deliberates the initiatives to identify the challenges and prescribes probable solutions to develop other dying ethnic traditions in the world after studding Nayagram as a model of development.

\section{KEYWORDS:}

Patachitra; Pater Gan; folk art; ethnic traditions; Nayagram-Pingla; fok art of West Bengal; Indian folk art. 


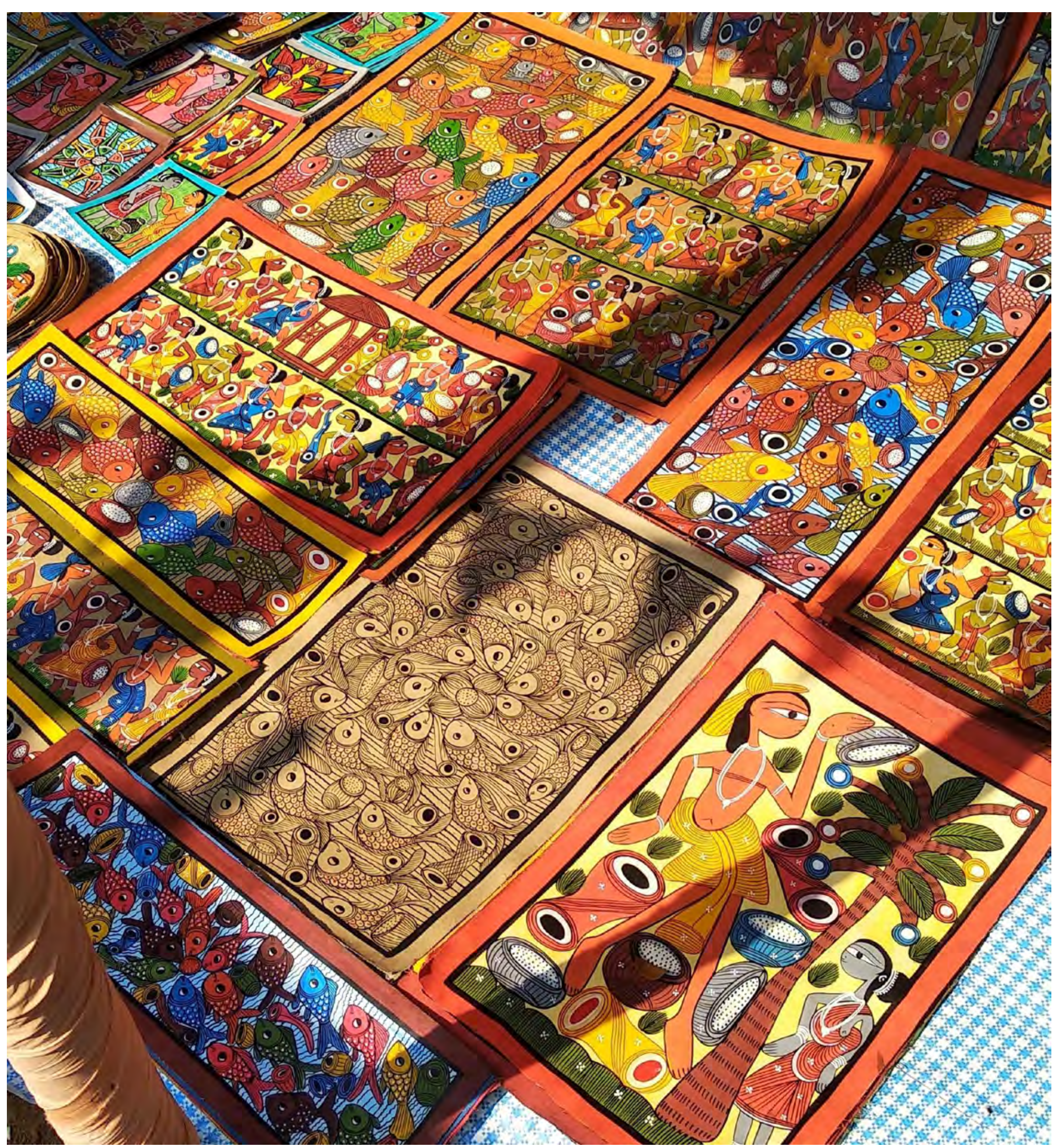

1. Патачитры.

Фото: П. Раха

1. Patachitras.

Photo by P. Raha

\section{Введение}

Эта статья посвящена деревне в Западной Бенгалии, где все жители - «патуа»". Они преимущественно художники, создающие особые произведения - патачитры. Патачитра - это народная традиция живописи, популярная, в основном, в штатах Восточной Индии, особенно в Западной Бенгалии и Одише [4; 8]. Свитки-патачитры предназначались для визуальной передачи народных песен-историй, которые получили название «патер ган» [3]. Их темой были, в основном, религиозные сюжеты, а также различные житейские истории [1].

Эти художники-патуа (они же - певцырассказчики и поэты-лирики) составляли характерную особенность древних восточно-индийских деревень [6]. Они ходили от двери к двери, демонстрируя свои картины-свитки, и пели-рассказывали истории, изображенные на свитках [2]. В обмен 


\section{Introduction}

This paper is focused on an especial village in West Bengal, where all the residents are 'Patuas'. Patuas are basically painters who paint 'Patachitras'. Patachitra is a folk tradition of painting, popular mainly in Eastern Indian states, especially in West Bengal and Odisha [4; 8]. These paintings were used to narrate the stories in folk songs, which are called Pater Gan [3]. Mainly religious stories and social issues were their subjects [1].

These multitalented painters as well as singers and lyricists known as Patuas were an iconic part of the ancient Eastern-Indian villages [6]. They used to go door to door to show the paintings in the form of scrolls and sang the story depicted in the scrolls in a sequence according to it [2]. The villagers provide money, food, cloth, and other daily needs to them in return for that wonderful entertainment. The Patachitras and the Patuasangeets were not only entertainment to the villagers but also a form of religious practice or social awareness [7] to be handed over to generation after generation. In the colonial and post-colonial period in India, these kinds of rural traditions, dependent on the self-dependent rural socio-economic ecosystem, got deprived. The Patuas of Nayagram, situated near Pingla in West Medinipur district of West Bengal, are one of the last surviving communities among the Patuas survived in that dark age of deprivation. In recent years some government and social organizations have come up to support this traditional art and artists. Nayagram is a mega project for them. This paper will try to reveal the journey of Nayagram from the early start to the present situation and the future possibilities and challenges. From the national perspective, this is a form of India's ancient traditional knowledge system, which should be restored as an ethnic culture.

On the other hand, international organizations like the United Nations Education, Scientific and Cultural Organization (UNESCO) are finding a sustainable lifestyle through this kind of traditional ethnocultural practices [4]. All these issues, struggles, opportunities, and ways of revival for traditional practices should be documented as a model to inspire in the future. This paper concludes with these objectives.

Objectives. This research paper aims to reveal the on-ground reality of the Patuas of Nayagram and their version of their past and present, and future aspirations.

Methodology. The research is mainly focused on the on-ground investigations with the field works and the interviews. To have an idea of Patachitra (Which is one of the oldest traditions of art in India), the researcher has taken the help of previous literature and research works before visiting Nayagram. This paper has considered two different viewpoints of two generations of artists to map the journey's ups and downs to reach this present status (of Nayagram) along with their future visions and expectations. At first, the senior-most artist of Nayagram, Syamsundar Chitrakar, was interviewed to get to know the real history of Nayagram; second, the young talented woman artist Sonia Chitrakar was interviewed to understand the present situation and how they are approaching the future. After understanding the on the ground situation, this paper has discussed the correlated socio-economic issues.

\section{Discussions \\ Patachitra}

Patachitra synthesizes the ethnic enigma with the struggle of marginality. The Patuas achieve aesthetic excellence through the struggle for life and the experience through it. Maybe their hardship is the main inspiration to be most simplistic and bold in art. The vibrant colour forces the viewer to notice the art as they sing loud and clear to send their voice to the every ear that is not listening. Their perception of art or painting is quite different from us. Usually they do not sign on their works. A painting is not a subjective issue for them. It is not only a form of entertainment. They want to tell the society about their culture and beliefs. They want to teach their future generation whatever they have realized about life. The lesson rolls generation after generation. They tell their stories attracting people by the brightly coloured paintings and loudly sung songs. There is nothing to hide and nothing to be emphasized. The simple motifs or patterns are repeating in an organic rhythm symbolizing the endlessness of life. The viewer has to be so observative to find the significant symbols or characters of the story while watching the Patachitra. The Patuas indicate those by their finger in the Patachitra while they sing the Pater Gan. Their subjects ${ }^{2}$ like 'Marriage of a Fish' or 'Marriage of a bird' have a deep allegorical meaning (Fig. 2-6). These show the fishes or birds are celebrating a marriage ceremony. Where they are eating food, playing music and dancing. On the other hand a big bird or fish is attacking them to eat them. Getting good food and getting married are basic needs of life for them. Celebration after it with song, music and dance is representing a happy and prosperous life. But it is not that easy. In a pond a big fish always eats the small ones. This fact is often recommended symbolizing the inequality in the society. This is an existential threat for the marginal communities like Patuas. They express this crisis through their art. They also depict the Hindu and Santali mythological stories. Here also the ultimate objective is to raise the moral of the society for sustainability in all regards.

\section{The Visit to Nayagram}

The nearest railway station to Nayagram (Fig. 7) is Balichak near Kharagpur Railway station of the Howrah Division of the Eastern Railways of India. From Balichak railways station, it takes about half an hour by car to reach Nayagram (Near Pingla).

The village Nayagram is an ideal example of rural beauty, along with the difficulties of interiority. All the 
на это жители деревни давали им деньги, еду, одежду и другие необходимые вещи. Однако это было не только развлечением для сельских жителей, но и формой религиозной практики, а также общественного информирования [7], передававшимися из поколения в поколение. В колониальный и постколониальный период в Индии эти виды сельских традиций, зависящие от самостоятельной сельской социально-экономической экосистемы, были почти утрачены.

Патуа деревни Наяграм, расположенной недалеко от Пинглы в районе Западный Миднапур в Западной Бенгалии, являются одними из последних выживших сообществ среди всех патуа, переживших этот темный век лишений. В последние годы некоторые государственные и общественные организации выступили в поддержку этого традиционного искусства; при этом деревня Наяграм стала своеобразным мега-проектом. В данной статье мы попытаемся раскрыть историю Наяграма от самого начала до сегодняшнего времени, а также представить основные проблемы и прогнозы. Данная традиция должна быть сохранена не только потому, что она является частью национальной культуры Индии, но и потому, что международные организации, такие как ЮНЕСКО, рассматривают подобные традиционные этнокультурные практики как модель устойчивого образа жизни [4]. Таким образом, целью исследования является анализ традиционных практик патуа на примере деревни Наяграм в контексте исторического развития и перспектив.

Методологическая база работы включает полевые исследования и экспертные интервью, а также анализ соответствующей литературы. В качестве экспертов были выбраны: старейший художник Наяграма Шьямсундар Читракар и молодая художница Соня Читракар. Помимо культурологических и искусствоведческих вопросов в статье затрагиваются и взаимосвязанные социальноэкономические проблемы.

\section{Обсуждение \\ Патачитра}

Искусство патачитра олицетворяет синтез красоты и тайны этничности с суровой борьбой за жизнь. Патуа достигают эстетического совершенства именно благодаря борьбе за жизнь и полученному через нее опыту. Может быть, невзгоды и вдохновили их на создание максимально простых и в то же время смелых, выразительных произведений. Яркий цвет свитков сразу привлекает внимание и одновременно заставляет зрителя слушать певцов-рассказчиков. Но их восприятие искусства очень отличается от нашего. Художникипатуа обычно не ставят подписи на своих работах, и картина для них - не личное самовыражение и не развлечение. Они хотят рассказать обществу о своей культуре и своих убеждениях, научить молодежь всему, что они поняли в жизни. Этот урок передается из поколения в поколение. При этом внешне в нем нет ничего загадочного: патуа рассказывают свои истории, привлекают людей яркими красками и громкими песнями. Простые мотивы или узоры повторяются в органическом ритме, символизирующем бесконечность жизни. Поэтому зритель должен быть очень наблюдательным, чтобы усмотреть важные символы, понять роль основных персонажей истории. Многие сюжеть ${ }^{2}$, такие как «Свадьба рыб» или «Свадьба птиц», имеют глубокий аллегорический смысл (рис. 2-6). Сюжет прост: рыбы или птицы празднуют свадьбу, едят, играют музыку и танцуют, но при этом на них нападает большая птица или рыба, пытаясь их проглотить. Рисунок отражает простые человеческие жизненные потребности и ситуации: хорошая еда, свадьба, празднование с песнями, музыкой и танцами - всё это символизирует счастливую жизнь. Но не всё так просто. В пруду большая рыба всегда поедает маленьких, и это символизирует вечное неравенство, которое особенно чувствительно именно для маргинальных сообществ, подобных патуа, и угрожает им исчезновением. Именно эту скрытую трагедию и угрозу они выражают своим искусством. Кроме того, на свитках часто изображаются индуистские и санталийские мифы, и здесь также просматривается главная цель - напомнить о вечных нравственных и духовных устоях.

\section{Поездка в Наяграм}

Ближайшая к Наяграму железнодорожная станция - Баличак около Кхарагпура (отделение Ховрах Восточных железных дорог Индии). От Баличака до Наяграма (около Пинглы) можно добраться на машине примерно за полчаса (рис. 7).

Деревня Наяграм - образец сельской красоты, несмотря на крайне простые интерьеры. Каждый дом представляет собой полноценную художественную мастерскую и обильно украшен патачитрами. Жители очень гостеприимны и щедры ко всем посетителям, даже женщины и дети чувствуют себя с ними свободно. При этом гость может быть как великим ученым, так и путешественником, бродящим по этому месту просто для разнообразия. Патуа без стеснения демонстрируют свое мастерство даже перед иностранцами, и любовь к искусству преодолевает все языковые барьеры. Это удивляет некоторых городских посетителей, которым трудно представить себе, как можно творить в трудных условиях сельской местности. Тем не менее их вдохновляет сама возможность видеть творчество в его самой непосредственной и спонтанной форме. 


\section{2. Патачитра на тему}

“Свадьба рыб”.

Патуа (художник)

Арати Читракар.

Наяграм, 2019.

В коллекции Sanath Art

Foundation (SAF),

Шимла, Индия.

Фото: П. Раха

\section{Marriage of the fish.}

Patachitra by Arati Chitrakar. Nayagram, 2019.

Collection of Sanath Art

Foundation, Shimla, India. Photo by P. Raha
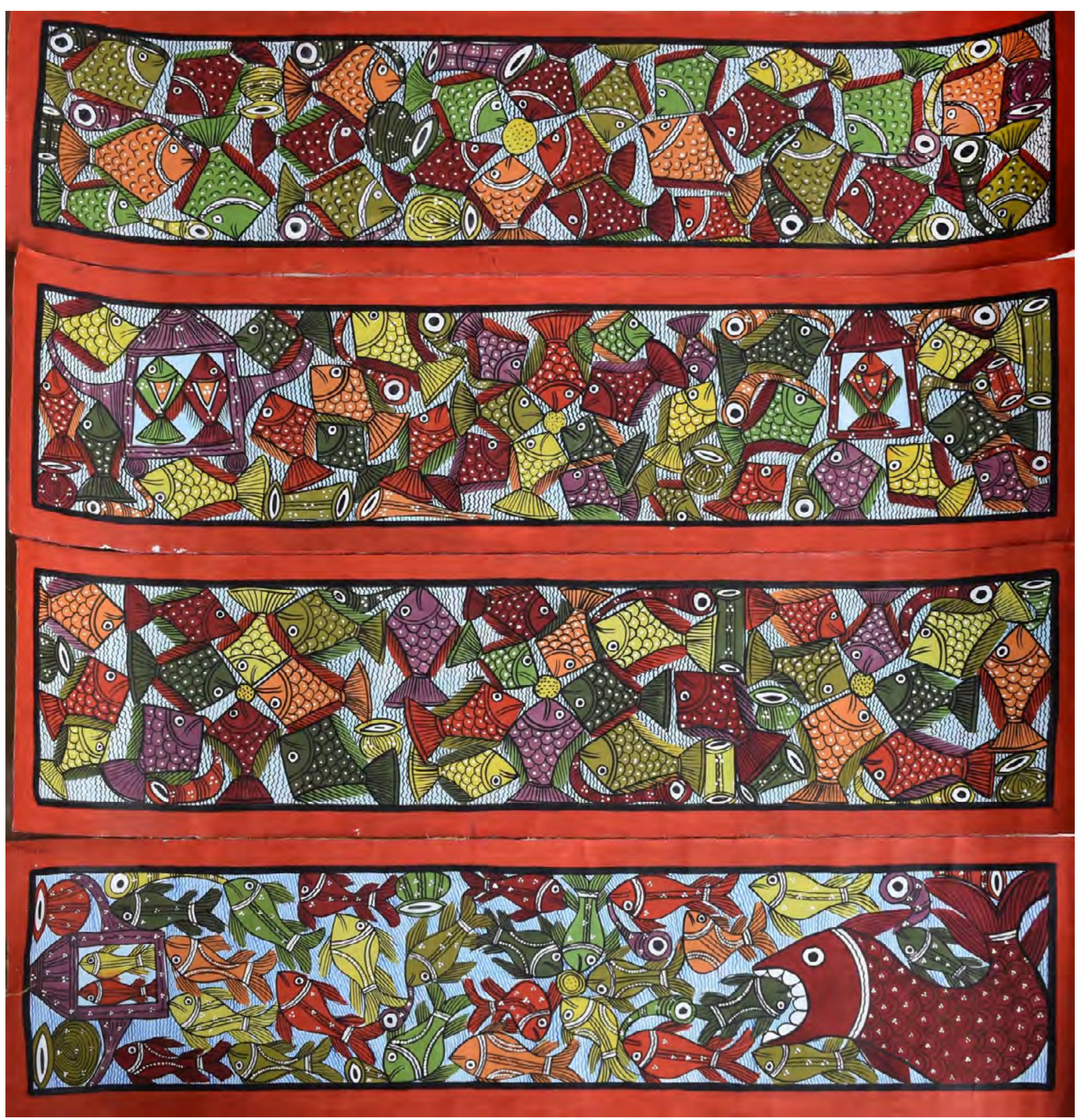

residents of Nayagram are Patuas. Every house is a full-fledged art workshop and well decorated with Patachitras. They are very generous and welcoming to all the visitors at their home. Even the women and children of their family are very comfortable with the visitors. The visitor may be a great scholar or a traveler roaming the place just for a change. The Patuas are very confident to show their art and perform the song accordingly, even in front of the foreigners. Love for art breaks all the language barriers. It may be surprising to some urban visitors who cannot imagine the aesthetic achievements of Patachitras done within the difficulties and challenges of this rural area. It is really inspiring to see creativity with the most simple and spontaneous way of presentation.

\section{The experience of a veteran Patua -} Shyamsundar Chitrakar

Shyamsundar Chitrakar is one of the most senior among the Patuas, lives at Nayagram (Fig. 8). His wife, Rani Chitrakar is also a notable Patuas. Shyamsundar Chitrakar is one of the earliest residents of Nayagram. 
Искусство Евразии

№1 (20) 2021 eISSN 2518-7767

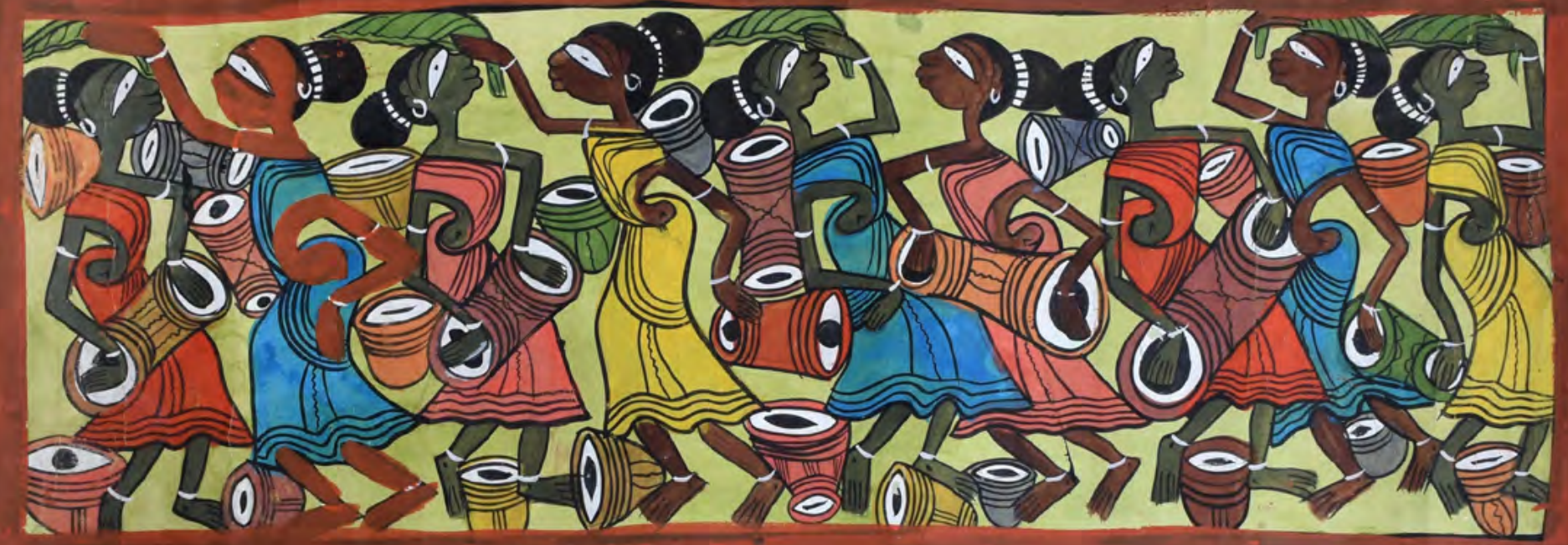

\begin{tabular}{l|l}
3 & \\
\hline 4 & 5
\end{tabular}

3. Патачитра на тему

“Сантальский танец".

Патуа (художник)

Соня Читракар.

Наяграм, 2019.

В коллекции Sanath Art

Foundation (SAF),

Шимла, Индия.

Фото: П. Раха

\section{Santal Dance.}

Patachitra by Sonia

Chitrakar. Nayagram, 2019. Collection of Sanath Art

Foundation, Shimla, India.

Photo by P. Raha
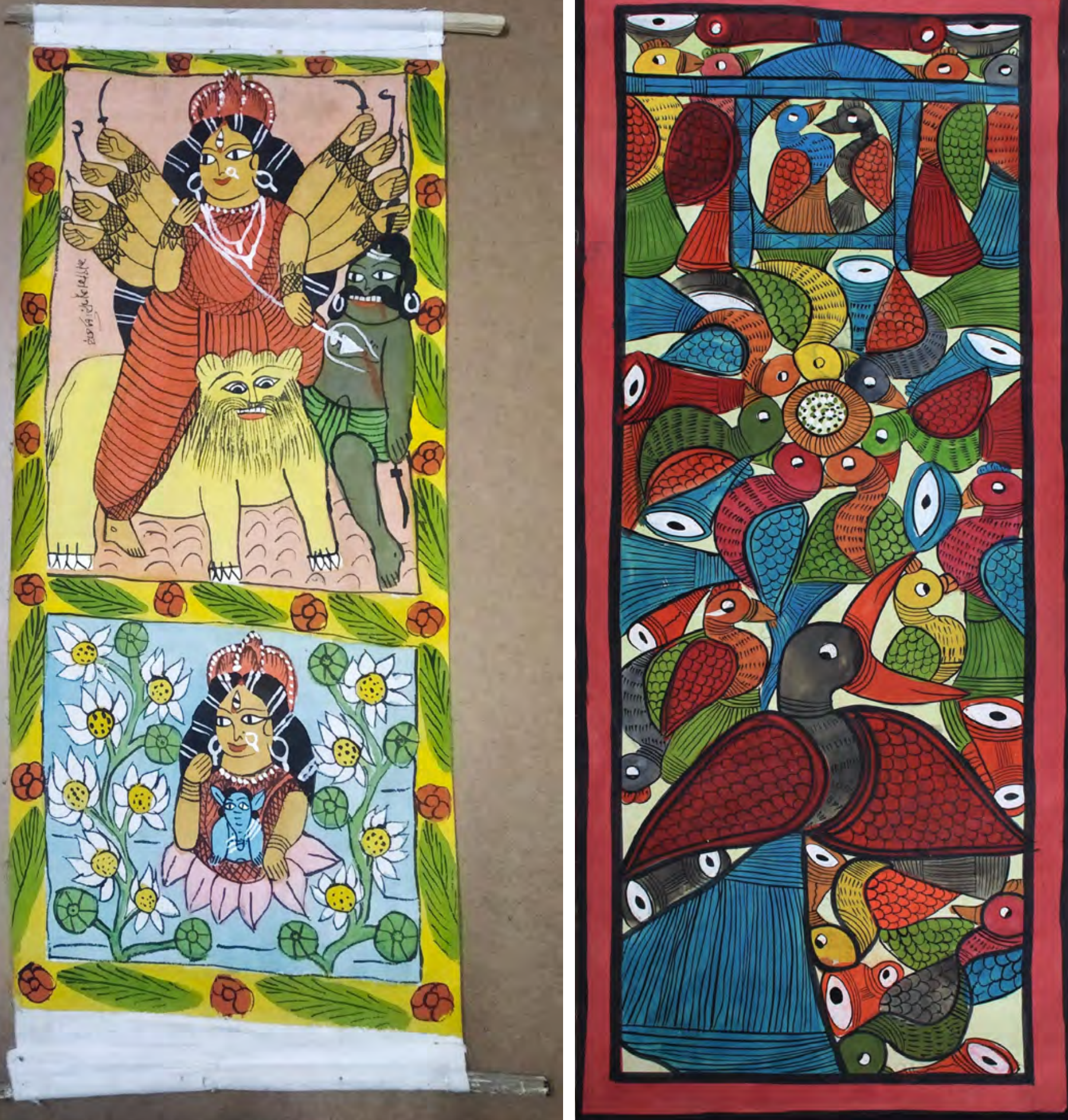

4. Патачитра

на тему «Дурга».

Патуа (художник)

Шьямсундар Читракар.

Наяграм, 2019.

В коллекции Sanath Art

Foundation (SAF), Шимла,

Индия. Фото: П. Раха

4. Durga. Patachitra by Shyamsundar Chitrakar Nayagram, 2019.

Collection of Sanath Art

Foundation, Shimla, India.

Photo by P. Raha

\section{5. Патачитра на тему}

“Свадьба птиц".

Патуа (художник)

Соня Читракар.

Наяграм, 2019.

В коллекции Sanath Art

Foundation (SAF)

Шимла, Индия.

Фото: П. Раха

5. Marraige of the bird.

Patachitra

by Nayagram-Sonia

Chitrakar. Nayagram, 2019

Collection of Sanath Art

Foundation, Shimla, India.

Photo by P. Raha 
It can be said that he has seen the birth, growing up, and flourishing of Nayagram at its present splendor. He knows every up and down of this journey. Many artists, poets, writers, and other intellectuals also come to Shyamsundar Chitrakar to be inspired and to be more creative. This interview with Shyamsundar Chitrakar was taken at Nayagram in the afternoon of April in the year of 2019 .

Patua Shyamsundar is very concerned and conscious about his art. He is not only concerned about the Patachitra but also the Pater Gan and its heritage. As a senior Patua he is concerned about the new generation of Patuas since they are less interested in learning history, religion, and social issues. He conveyed his disappointment, stating that most of the young Patuas do not even try to write new songs or sing the Pater Gan (song). As an experienced artist Shyamsundar told many essential factors of Patachitra in terms of method and materials. He demonstrated how the colours are prepared by the different vegetative and mineral elements. He believes that art is incomplete without its inherent philosophy, and it must teach society something at least. It is also very surprising that a person of a marginal community without institutional education has a very clear view of life as a human and about art as an artist. The Bengali word 'Bidagdha' means someone who was burnt a lot to bring out the most solid, pure, and precious part out of him or her. Only this word can describe an artist like Shyamsundar Chitrakar and the excellence of his personality, which may be very simple and down to earth, but there was no sign of inferiority. Within the first few seconds of that interview, the pre-planned questioners and the only data seeking strategy was forgotten. The epical journey of the Patuas has been performing by the great Patua Shyamsundar Chitrakar, who has the charismatic talent of storytelling in his blood. The listener has no choice except let his/her mind to go with the flow of the story. When Shyamsundar was asked: how was everything started at Nayagram? He replied it was 50 to 60 years ago, in his young age, he came to live at Nayagram with his wife Rani Chitrakar. At that time, there were only four families of Patuas at Nayagram. They were the family of Maneswar Chitrakar, the family of Gunadhar Chitrakar, the family of Bamacharan Chitrakar, and the family of Joti Chitrakar. Maneswar Chitrakar was the father of Rani Chitrakar and father-in-law of Shyamsundar Chitrakar. Shyamsundar was also telling that, before starting to live at Nayagram the Patuas used to come to this place for performing Pater Gan and to show the scrolls (Patachitra). There was a very kind man Gunadhar Bishal who lived in Nayagram. Gunadhar Bishal was a farmer who was the owner of a vast land at that area where the present Nayagram was established. According to Shyamsundar Chitrakar, Gunadhar was a great lover of the art of Patachitra and Pater Gan. The Patuas come to Gunadhar's house from very far. Gunadhar used to allow the Patuas to stay at his house at night. Shyamsundar explained the situation very well. There was no mobile or television. After the hardship of all the day long, the farmers used to enjoy the Patuasangeet or Pater Gan along with the beautiful Patachitras at the yard of Gunadhar Bishal's house. Shyamsundar Chitrakar continued by stating how gradually artists and the villagers, especially Gunadhar Bishal made a bond through the love for art and music of Patachitra and Pater Gan. Shyamsundar was telling that in their community, they cannot refuse someone who wishes to stay with them at their house. They cannot even think to do that. So as a lover of art, Gunadhar Bishal happily allowed the talented Patuas to stay at his home. Subsequently, their families and other relatives started to come (who were Patuas also), to Gunadhar's place. Gunadhar allowed them to build huts in his territory. As mentioned above, Shyamsundar was one of those first generations of Patuas who came to that place. According to him, initially they used to perform Pater Gan and show the Patachitras at that village in Pingla and surroundings for livelihood. Gradually they got able to buy the land (where they had been already living) from Gunadhar Bishal and his successors. Thus the village of Patuas, Nayagram was established. After some years of struggling, these Patuas got attention from the Government. The Government spotted the potential of this place in terms of ethnocultural values. Due to old age, Shyamsundar Chitrakar could not remember the exact year but mentioned it as a remarkable event. He also mentioned the name of Amit Kiran Dev, who was the District Magistrate of Medinipur at that time along with Animesh Pal who was the principal of Medinipur College and some other higher police officials, came to Nayagram to investigate the situation of Patuas. The Patuas performed their Pater Gan along with showing the Patachitras. According to Shyamsundar Chitrakar, the government officials were highly impressed by their works of Patachitra and Pater Gan. After the performance, the government officials asked the Patuas of Nayagram about their problems and living difficulties. Shyamsundar Chitrakar emphasized the most on the demand for a road near to the village Nayagram among all other demands of the Ptuas of that time. Shyamsundar believes the road is the main lifeline of Nayagram. Fortunately, the road was constructed. According to him, after getting the road, Nayagram was revitalized. For easier connectivity with Kolkata, many visitors started to come. Most of them were scholars, researchers, artists, and writers. Many journalists also start to come to visit Nayagram. Shyamsundar was describing it as the resurrection of Nayagram. He was also saying that as Nayagram was getting attention more and more, the Patuas from other remote places of West Bengal like Ghatal, Nandigram, 


\section{Опыт ветерана Патуа - \\ Шьямсундара Читракара}

Шьямсундар Читракар - один из самых старших и самых первых жителей патуа, живущих в Наяграме (рис. 8). Его жена, Рани Читракар, также патуа. Можно сказать, что он видел рождение, взросление и расцвет Наяграма в его нынешнем великолепии; все взлеты и падения на этом пути. Многие художники, поэты, писатели приходят к нему, чтобы почерпнуть вдохновение. Мы провели интервью с Шьямсундаром Читракаром во второй половине дня в апреле 2019 года.

Патуа Шьямсундар - глубокий знаток искусства патачитры и патер ган. Как старший патуа он обеспокоен новым поколением, мало, на его взгляд, заинтересованным историей, религиозными вопросами и даже социальными проблемами. Он выразил разочарование в том, что большинство молодых патуа не пытаются писать новые песни патер ган и даже исполнять их.

Как опытный художник Шьямсундар рассказал о многих существенных аспектах искусства патачитры с точки зрения используемых материалов и методов. Он продемонстрировал нам, как изготовляются краски из различных растительных и минеральных элементов. При этом Шьямсундар считает, что искусство неполно без присущей ему философии, и оно должно хоть чему-то научить общество. Нас поразило то, что человек из маргинального сообщества, без институтского образования имеет очень четкое представление о жизни как человек и об искусстве как художник. Бенгальское слово «Бидагдха» означает что-то, что подверглось обжигу для извлечения самой прочной, чистой и драгоценной части, - и лишь этим словом можно охарактеризовать такого художника, как Шьямсундар Читракар. В течение первых нескольких секунд этого интервью заранее запланированные анкеты и планы сбора данных были забыты, и настоящее эпическое путешествие по истории патуа совершил сам великий патуа Шьямсундар Читракар, у которого в крови талант рассказчика.

Когда Шьямсундара спросили об истории Наяграма, он ответил, что 50-60 лет назад в юном возрасте он переехал жить сюда со своей женой Рани Читракар. В то время в Наяграме было всего четыре семьи патуа: семья Манесвара Читракара, семья Гунадхара Читракара, семья Бамачарана Читракара и семья Джоти Читракара. Манесвар Читракар был отцом Рани Читракара и тестем Шьямсундара Читракара. Шьямсундар также рассказал, что до того, как поселиться в Наяграме, патуа приходили сюда, чтобы исполнить патер ган и показать свитки патачитр.

В Наяграме в то время жил Гунадхар Бишал, очень отзывчивый человек, фермер, который владел огромной землей в том районе, где была ос- нована нынешняя Наяграм. Гунадхар был большим поклонником искусства патачитры и патер ган, и в его дом издалека приходили патуа-художники и исполнители, часто оставаясь на ночь. Не было ни мобильной связи, ни телевидения, и после дневных трудов фермеры наслаждались песнями патер ган и созерцанием ярких свитков во дворе дома Гунадхара Бишала. Шьямсундар Читракар рассказал, как постепенно художники и сельские жители, особенно Гунадхар Бишал, сблизились благодаря любви к искусству и музыке патачитры и патер ган. Он добавил, что в их общине они не могут отказать гостям в ночевке, поэтому как любитель искусства Гунадхар Бишал с радостью позволил талантливым патуа остаться у себя. Впоследствии к Гунадхару стали приходить семьи художников и другие родственники (которые тоже были патуа). Гунадхар разрешил им построить хижины на своей территории.

Как упоминалось выше, Шьямсундар был одним из первых патуа, пришедших в это место. По его словам, изначально они исполняли патер ган и показывали патачитры в этой деревне, в Пингле и окрестностях для заработка. Постепенно они смогли купить землю (на которой они уже жили) у Гунадхара Бишала и его преемников. Так была основана деревня Наяграм.

После нескольких лет борьбы патуа привлекли внимание правительства. Оно оценило потенциал этого места с точки зрения этнокультурных ценностей. Из-за преклонного возраста Шьямсундар Читракар не мог вспомнить точный год, но назвал это знаменательным событием. Он также упомянул имя Амит Киран Дев, который в то время был окружным магистратом в Миднапуре, вместе с Анимеш Пал, директором колледжа Миднапура, и некоторыми другими высшими чиновниками. Они приехали в Наяграм, чтобы изучить ситуацию на месте. Патуа исполнили патер ган вместе с показом патачитр. По словам Шьямсундара Читракара, правительственные чиновники были очень впечатлены и после выступления спросили жителей Наяграма об их проблемах и жизненных трудностях. Шьямсундар Читракар особо выделил потребность в дороге и, к счастью, та действительно вскоре была построена. По его словам, после этого Наяграм очень оживился. Из Калькутты начали приходить многие посетители. Большинство из них были учеными, художниками и писателями. Многие журналисты также начали приезжать сюда, и Шьямсундар описывал это как воскрешение Наяграма. Он отметил, что по мере того, как Наяграм привлекал к себе всё большее внимание, патуа из других отдаленных мест Западной Бенгалии, таких как Гхатал, Нандиграм, Дьябра и Пашкура, начали переезжать сюда, чтобы жить вместе с другими патуа и развивать свое искусство. Шьямсундар 
6. Патачитра на тему

“Свадьба рыб».

Патуа (художник)

Сануар Читракар.

Наяграм, 2019.

Фото: П. Раха

6. Marraige of the fish.

Patachitra by Sanuar

Chitrakar. Nayagram, 2019.

Collection of Sanath Art

Foundation, Shimla, India.

Photo by P. Raha

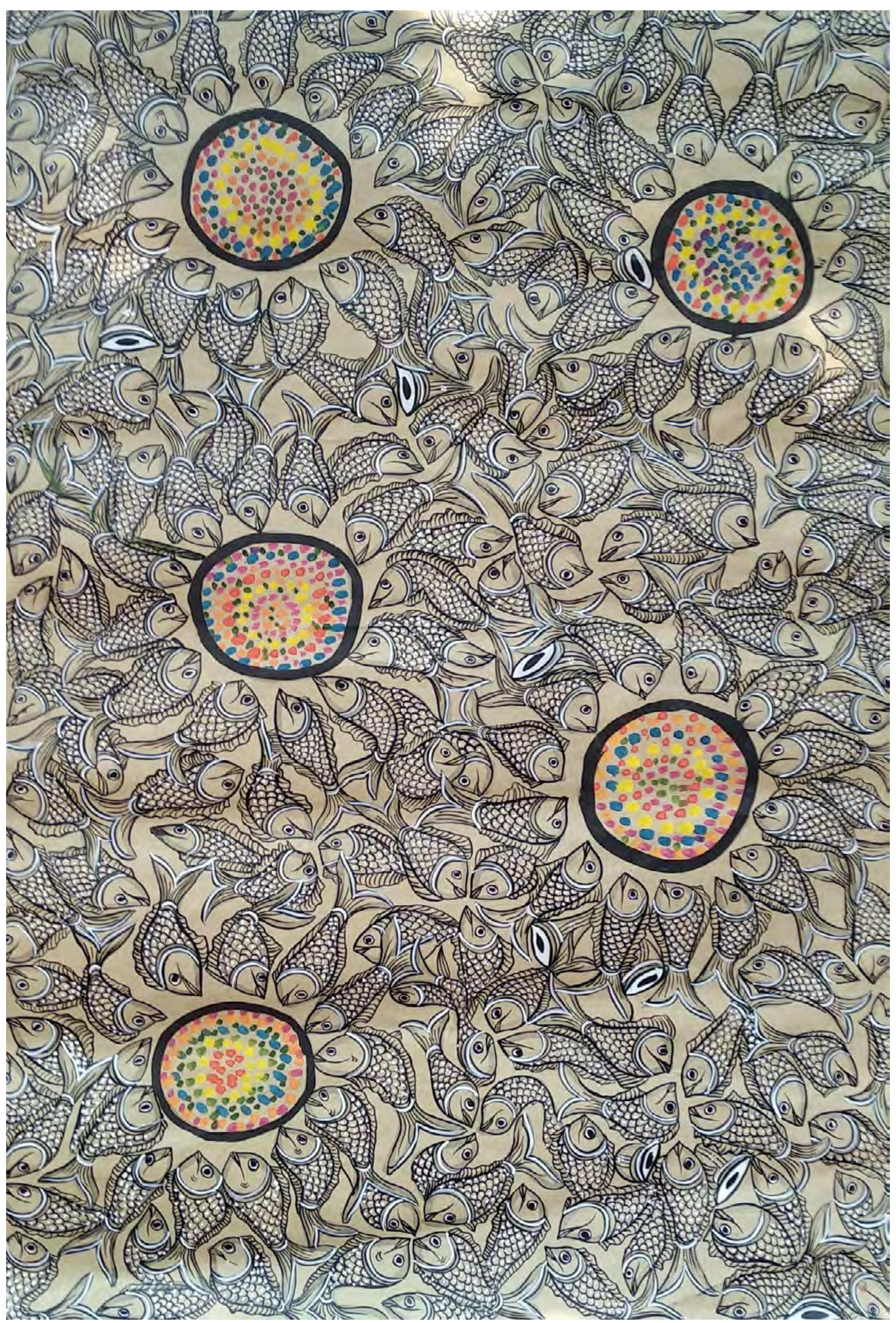




\section{Искусство Евразии}

\section{№1 (20) 2021 elSSN 2518-7767}

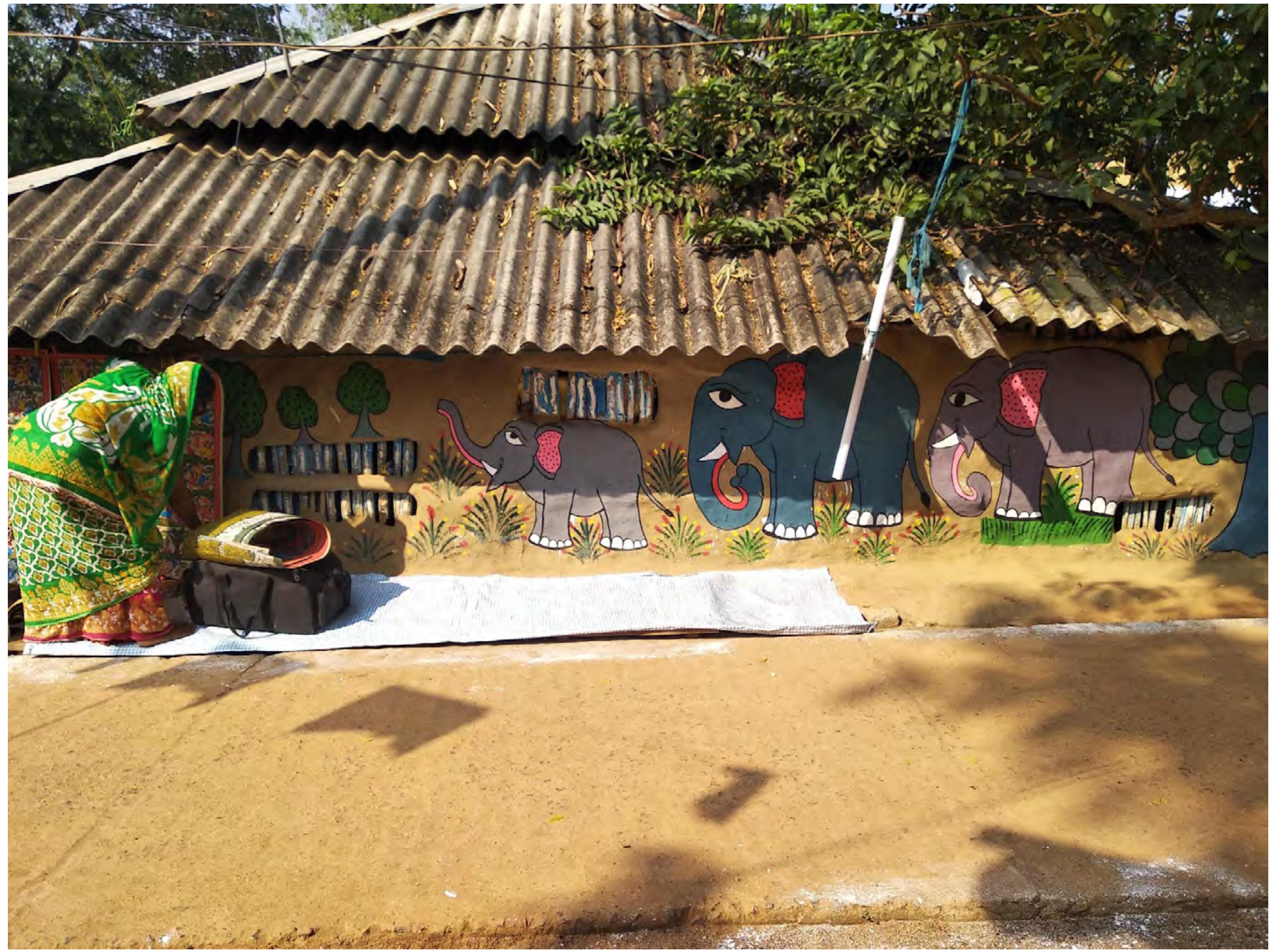

отметил, что все жители Наяграма - родственники, и они часто звонили другим своим родным, увлеченным традиционным искусством патачитры. В итоге сейчас в Наяграме насчитывается около 65 семей патуа, процветающих благодаря искусству патачиры и патер ган.

Шьямсундар Читракар также сказал, что сегодня им очень помогает неправительственная организация под названием «Бангла Наток Дот Ком». Каждый год в декабре они устраивают большой фестиваль искусств «Патмая» в Наяграме, на который собирается большое число посетителей, они покупают патачитры и слушают выступления. В заключение Шьямсундар заявил, что все патуа должны помнить свою историю и подлинные традиции, а правительство должно сосредоточить внимание на образовании и развитии детей патуа, которые являются будущим этой традиции.

\section{Соня Читракар - луч будущего}

Прежде чем представить молодую художницупатуа Соню Читракар (рис. 9), следует вспомнить о довольно сложном статусе женщин в социальной структуре сельской Бенгалии, особенно на западе Мединипура, и в частности в таком социальноэкономически маргинальном сообществе, как патуа. Здесь надо упомянуть еще один момент. Все патуа, живущие в Наяграме, являются мусульманами по вероисповеданию. Это удивительно, так как их имена (Шьямсундар Читракар, Гурупада Читракар и др.) не похожи на мусульманские, а звучат как индуистские имена.
7. Вид на Наяграм со стороны дороги. 2019.

Фото: П. Раха

7. A road side view at Nayagram.

Photo by P. Raha 
Dyabra, and Pashkura started to come to Nayagram to live with the Patuas and to pursue their won ancestral traditional practice. Shyamsundar says all residents of Nayagram are relatives, and gradually, they are calling their other relatives who love to draw Patachitras and love to sing the Pater Gans. Once it was started by only four families, now there are around 65 families of Patuas prospering with the art of Patachira and Pater Gan. Shyamsundar Chitrakar also told that at preset time the NGO named Bangla Natok Dot Com is working very well for them. They are arranging a large art festival called 'Patmaya' at Nayagram in every year on the month of December where numerous visitors come and buy their art and appreciate their performances. Shyamsundar concluded by stating that all Patuas should remember the true history and the authentic tradition, and the Government should focus on the educational development for the children of the Patuas who are the future of this tradition.

\section{Sonia Chitrakar - a ray of future}

Before introducing the young woman Patua Sonia Chitrakar (Fig. 9), the status of women in the coherent social structure in rural Bengal, especially in west Medinipure and more specifically in a socioeconomically marginal community as Patuas, should be kept in mind. Here, another point is mentionable. All the Patuas living in Nayagram are Muslims by religion. It is really, very surprising. Because generally, their names are like Shyamsundar Chitrakar (Male), Gurupada Chitrakar (Male), Gunadhar Chitrakar (Male), Jaba Chitrakar (Female), Rani Chitrakar (Female), and Swarna Chitrakar (Female), which do not sounds like Muslim names but sounds like Hindu names.

A significant part of their contents of Patachitras and Pater Gans are taken from Hindu mythologies. The surname Chitrakar does not clarify properly any religious affiliation. The Bengali word 'Chitrakar' means the artist or the painter. Sonia has admitted during the interview that she is Muslim by religion like all other Patuas of Nayagram. It enhances their marginality more. Therefore, raising as a successful artist, as a woman in this difficult socio-religious and socioeconomic condition, is an important matter of study. Sonia Chitrakar shared that she felt very fortunate when she got an opportunity to visit Germany to represent a form of Indian folk art like Patachitra and Pater Gan on an international stage. Apart from that, she has participated in several art fairs all over India. She participates at all the fairs arranged by Govt. of West Bengal. The annual Hastashilpa Mela arranged by the Government of West Bengal is notable among them. Sonia has already won the state-level award from a state-level completion arranged by the 'Directorate of Micro, Small \& Medium Enterprises of Government of West Bengal' in the year 2017. Now she is 21 year old. Her mother Jaba Chitrakar is also a renowned woman
Patua. Sonia Chitrakar's husband is Mustafa Chitrakar, who is also a very talented Patua. According to Sonia, the entire family of Patuas and their endless support are the biggest inspiration to her to prosper as much as possible. She has not forgotten to mention the support and guidance of members of the NGO named Bangla Natok Dot Com. In recent times the NGO Bangla Natok Dot Com has done a lot to bridge the marginalized and unrecognized talents of the Patuas of Nayagram with the rest of the world. Sonia Chitrakar elaborately described the detailed activities of Bangla Natok Dot Com at Nayagram. These activities were to develop the marketing system of Patachitras and to give the Patuas the platform they deserve. Sonia said that the members of Banla Natok Dot Com helped them to learn the basics of English and Hindi to communicate with the customers. Sonia and her fellow Patuas have learnt to decorate the dresses (t-shirt, saree, rumal, kurta etc.) and other decorative and utility products in the Patachitra style by the help of the artists hired by the Bangla Natok Dot Com. That was really very helpful to enhance the number of customers. Sonia was busy with her commission works in her house at Nayagram during this interview. She was decorating t-shirts with the motifs of Patachitras. She was talking and working continually. She was full of vibe and daring to dream. This vibe and fearlessness indicate the brightness of the future of Patuas, especially the women of Nayagram.

\section{Findings, Conclusion and Farther Studies}

The real experience is always greater than the bookish knowledge because writing the entire thing in a consolidated form is a very difficult task. This is true for this paper as well. This research paper was focused to investigate the Past and present of the Patuas of Nayagram and to have a presumption about their future. This paper finds the earliest Patuas of Nayagram: Maneswar Chitrakar, Gunadhar Chitrakar, Bamacharan Chitrakar and Joti Chitrakar, who got the support and the land to reside from a wealthy framer of that area who was Gunadhar Bishal. These things are the statement of one of the most senior and veteran Patua of Nayagram, who is Shyamsundar Chitrakar. According to Shyamsundar Chitrakar, he was encouraged to come and live and pursue the practice of Patachitra and Pater Gan at Nayagram by his father in law Maneswar Chitrakar, around 50 to 60 years ago. Life was not as fast as it is today. Therefore, it can be presumed that everything was started at least 50 years back from the time of Shyamsundar started to live at Nayagram. So, it is a history of more than a hundred years. The milestones of this historical evolution should be documented properly. Like how the government officials like Amit Kiran Dev (District Magistrate of that time) has noticed them and under which scheme or program they got the facilitation, are also the matter 
Значительная часть содержания патачитр и песен-сказаний патер ган заимствована из индуистских мифологий. Фамилия Читракар не указывает прямо на религиозную принадлежность. Бенгальское слово «Читракар» означает «художник, живописец». Соня призналась во время интервью, что она мусульманка, как и все другие патуа Наяграма. Это, отметим, вносит свой вклад в их маргинализированное положение. Поэтому для нас было важным понять, как женщина в непростых социально-религиозных и социально-экономических условиях стала известной художницей.

Соня Читракар рассказала, что ей очень повезло, когда у нее появилась возможность посетить Германию, чтобы представить такие формы индийского народного искусства, как патачитра и патер ган, на международной арене. Кроме того, она участвовала в нескольких ярмарках искусства, проходивших по всей Индии, а также в ярмарках, организуемых правительством Западной Бенгалии (среди них следует отметить ежегодную ярмарку Хасташилпа Мела). Соня уже получила награду государственного уровня по результатам государственного экзамена, организованного Управлением правительства Западной Бенгалии по делам микро-, малых и средних предприятий в 2017 году. Сейчас ей 21 год. Ее мать, Джаба Читракар, также известна среди патуа. Муж Сони Читракар - Мустафа, также талантлив; и в целом, поддержка семьи для нее всегда была очень важна. Кроме того, она с благодарностью говорит о поддержке со стороны членов неправительственной организации «Бангла Наток Дот Ком». В последнее время эта организация многое делает для того, чтобы установить связи между маргинализированными и недостаточно признанными талантами патуа деревни Наяграм и остальным миром. Соня Читракар подробно описала деятельность организации в Наяграме. Ее мероприятия были направлены на развитие маркетинговой системы для продажи патачитр и на предоставление художникампатуа платформы для показа своих работ, чего они вполне заслуживают. Соня сказала, что члены организации помогли им выучить основы английского и хинди для общения с клиентами. Соня и ее товарищи научились украшать платья (футболки, сари, румаль, курта и т.д.) и создавать другие декоративные полезные изделия в стиле патачитра с помощью «Бангла Наток Дот Ком», что очень помогло увеличить число клиентов. Как раз во время этого интервью Соня выполняла заказы в своем доме в Наяграме: украшала футболки мотивами патачитры. Она была полна энергии, и ее уверенность и бесстрашие указывают на яркое будущее патуа, особенно женщин Наяграма.

\section{Выводы, заключение и дальнейшие исследования}

Настоящий опыт всегда полнее книжных знаний, поэтому изложить все наши впечатления и результаты в одной статье было очень сложной задачей. В качестве основного вывода отметим, что история патуа в деревне Наяграм, формы продвижения традиции патачитры на мировую арену, разработка путей ее дальнейшего развития могут быть полезны в качестве модели дальнейших исследований схожих этнических традиций.

\section{Примечания}

1. Патуа - общины, расположенные в штатах Западная Бенгалия, Бихар, Джаркханд и Одиша в Индии и некоторых частях Бангладеш.

2. Патачитры не имеют специальных названий. Патуа разрабатывают традиционные темы, такие как «Свадьба рыб» и другие. 


\section{8. Шьямсундар Читракар} разворачивает свиток и поет «патер ган». 2019. Фото: П. Раха

\section{Shyamsundar} Chitrakar is unfolding the scroll along with performing Pater Gan to tell the story.

Photo by P. Raha

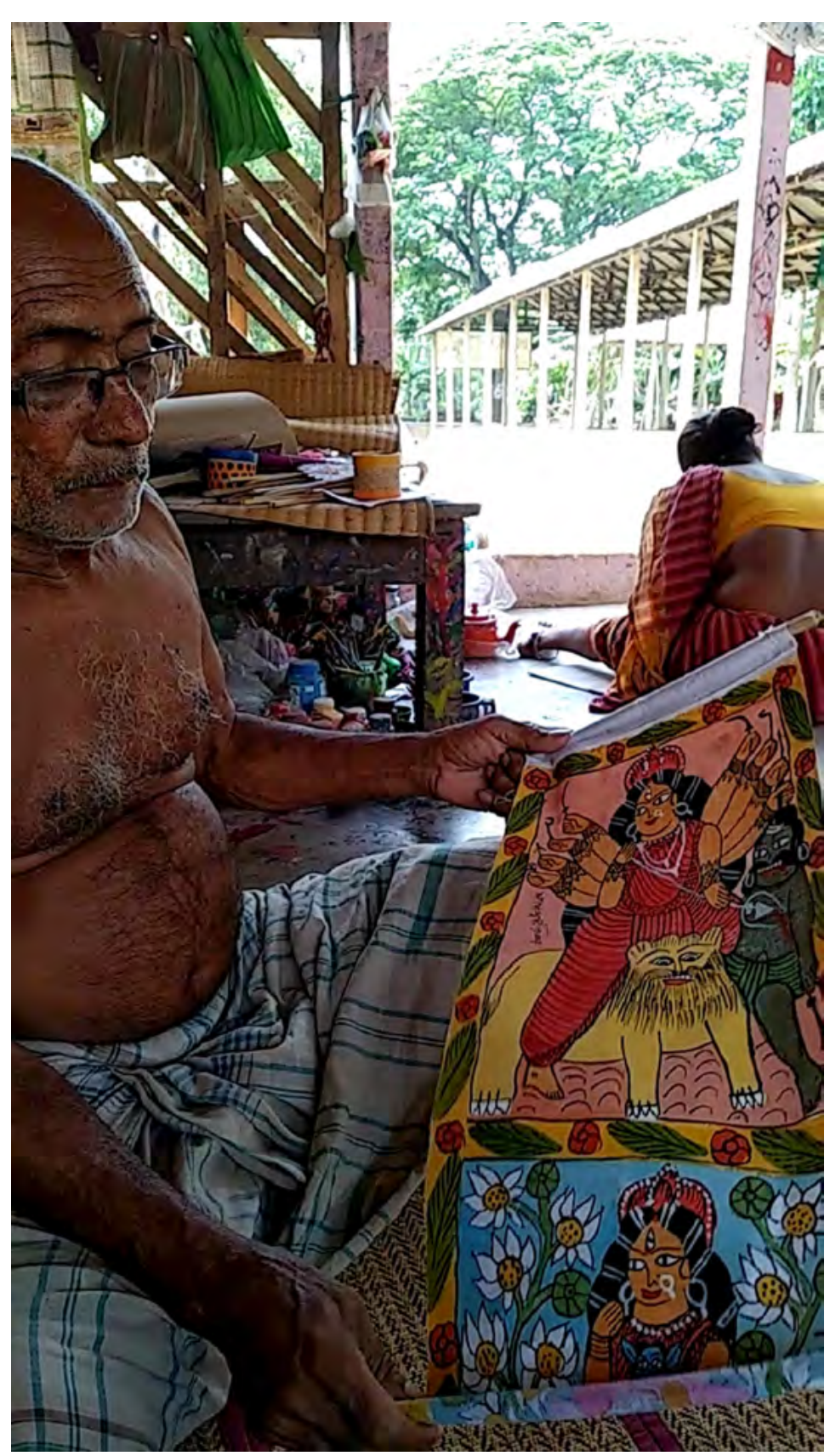

of further research. The enthusiasm and dedication of Sonia Chitrakar are representing the future progressiveness of the art of Patachitra and Pater Gan. The innovative interventions like decoration of utility items like umbrellas, lamps, and dresses by the motifs of Patachitras are enhancing the wider market. The NGOs like Bangla Natok Dot Com are coming forward to bridge this ethnic culture with the mainstream under the several developmental projects announced by the Government of West Bengal, Government of India, and the international organizations like UNESCO.

The rise of Nayagram with its struggle and potential as represented in this paper may be useful as a development model for further studies of similar ethnic traditions.

\section{Notes}

1. Patuas are communities located in the states of West Bengal, Bihar, Jharkhand and Odisha in India and parts of Bangladesh.

2. Patachitras do not have particular titles. Patuas work on popular themes. Such as the 'marriage of the fish' is a popular theme. 
Искусство Евразии

№1 (20) 2021 eISSN 2518-7767

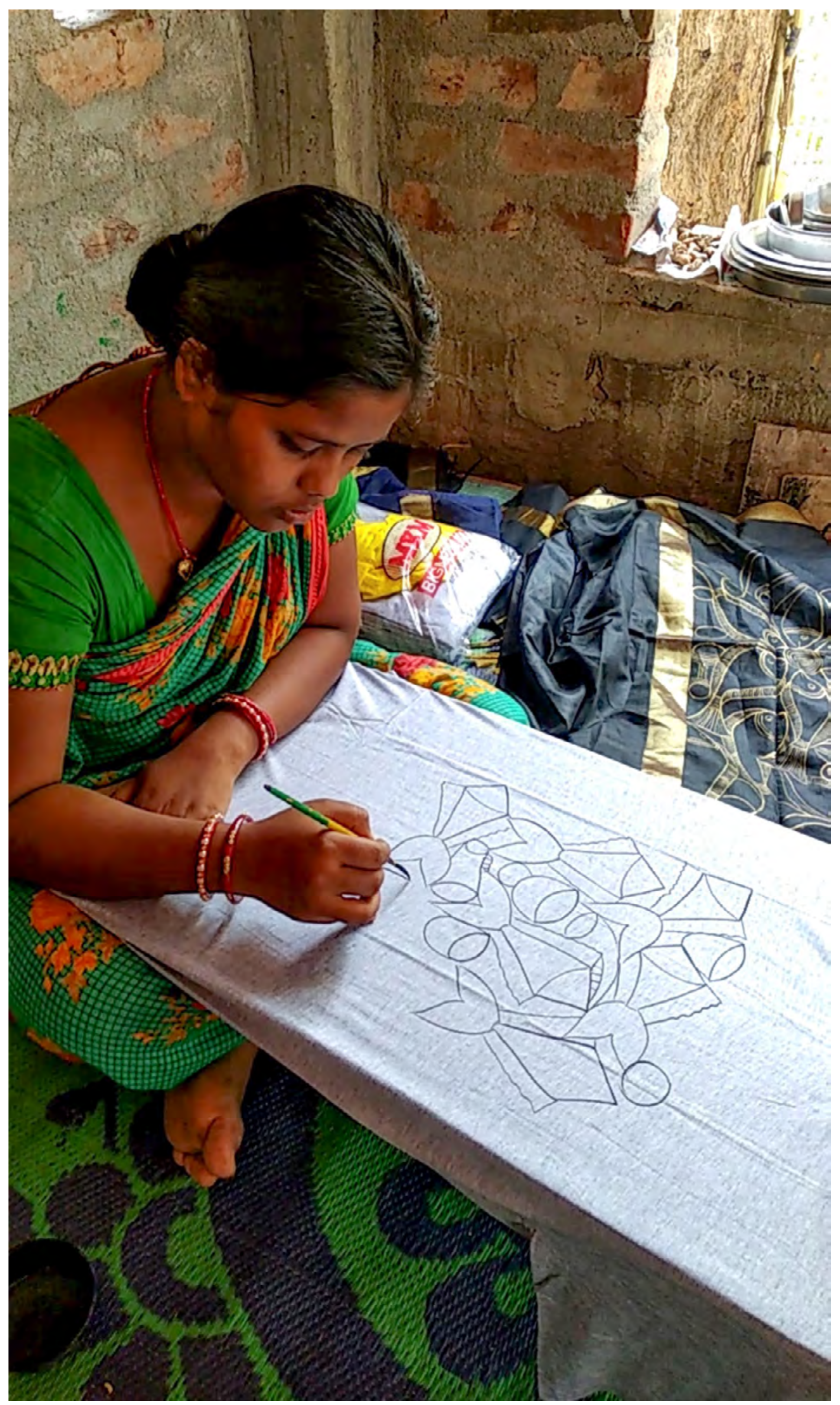

\section{9. Соня Читракар за работой.}

2019.

Фото: П. Раха

9. Patua Sonia Chitrakar is busy at her work.

Photo by P. Raha 


\section{Литература}

1. Bhattacharyya D. Folk Arts and Crafts of India // Bulletin of the R.K. Mission Institute of Culture. 1961. № 17 (2). P. 26 -30.

2. Dutt G. Folk Arts and Crafts of Bengal. Kolkata: Seagull Books Pvt. Ltd, 1932. 155 p.

3. Dutt G. Potua sangeet. Kolkata: Chhonya, 2016. 152 p. (In Bengali).

4. Hoshegrahar J. Culture at the Hurt of SDG // The UNESCO Courier [e-journal], 2017, April-June.

URL: https://en.unesco.org/courier/april-june-2017/culture-heart-sdgs (дата обращения: 11.10.2020).

5. Jain J. (ed.). Other Masters: Five Contemporary Folk and Tribal Artists of India. Gurugram: South Asia Books, 1998.88 p.

6. Kramrish S. Unknown India: Ritual Art in Tribe and Village. Philadelphia: Museum of Art, 1968. 127 p.

7. Mookherjee A.K. Folk Art of Bengal. Kolkata: University of Calcutta, 1964. 49 p.

8. Sharmila Ch. The Patuas of West Bengal and Odisha: An Evaluative Analysis. Mumbai: Himalaya Publishing House, 2017.184 p.

\section{References}

1. Bhattacharyya D. Folk Arts and Crafts of India. Bulletin of the R.K. Mission Institute of Culture (Golpark, Kolkata), 1966, No. 17 (2), pp. 26-30.

2. Dutt G. Folk Arts and Crafts of Bengal. Kolkata, Seagull Books Pvt. Ltd, 1932. 155 p. (Reprinted: 1990).

3. Dutt G. Potua sangeet. Kolkata, Chhonya, 2016. 152 p.

4. Hoshegrahar J. Culture at the Hurt of SDG. The UNESCO Courier [e-journal], 2017, April-June.

Available at: https://en.unesco.org/courier/april-june-2017/culture-heart-sdgs (accessed 11.10.2020).

5. Jain J. (ed.). Other Masters: Five Contemporary Folk and Tribal Artists of India. Gurugram, South Asia Books, 1998.88 p.

6. Kramrish S. Unknown India: Ritual Art in Tribe and Village. Philadelphia, Museum of Art, 1968. 127 p.

7. Mookherjee A.K. Folk Art of Bengal. Kolkata, University of Calcutta, 1964. 49 p.

8. Sharmila Ch. The Patuas of West Bengal and Odisha: An Evaluative Analysis. Mumbai, Himalaya Publishing House, 2017. 184 p.

ИНФОРМАЦИЯ ОБ АВТОРЕ: Раха Просенджит - магистр изящных искусств, аспирант, младший научный сотрудник, факультет изобразительного искусства, Университет штата Химачал-Прадеш, г. Шимла, Индия. E-mail: Prosenjitraha002@gmail.com

Перевод с английского: И.Е. Фотиева.

ABOUT AUTHOR: Raha, Prosenjit — Ph.D. Scholar, Master of Fine Art, Junior Research Fellow, Department of Visual Art, Himachal Pradesh University, Shimla, India. E-mail: Prosenjitraha002@gmail.com

Translated from English by I.V. Fotieva.

\section{Для цитирования |For citation:}

Раха П. Патуа из Наяграма: путь, взлеты и падения // Искусство Евразии [Электронный журнал]. 2021. № 1 (20). С. 32-47. DOl: https://doi.org/10.46748/ARTEURAS.2021.01.003 URL: https://eurasia-art.ru/index.php/art/article/view/175

Raha P. The Patuas of Nayagram: a journey and its ups and downs. Iskusstvo Evrazii - The Art of Eurasia, 2021, No. 1 (20), pp. 32-47. DOl: https://doi.org/10.46748/ARTEURAS.2021.01.003 Available at: https://eurasia-art.ru/index.php/art/article/view/175 (In Russian). 